\title{
Hospitality and tourism students: Are they ready for entrepreneurship?
}

\author{
Pulhin, Jeninah Christia $\$ \\ Lyceum of the Philippines University-Batangas, Philippines (jcdborbon@lpubatangas.edu.ph)
}

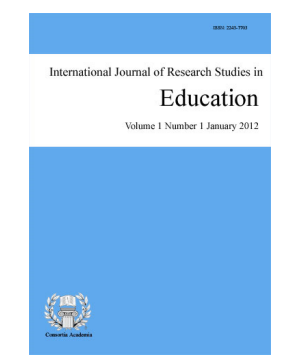

ISSN: 2243-7703 Online ISSN: 2243-7711

OPEN ACCESS

\section{Abstract}

One of the career options of hospitality and tourism students is venturing into entrepreneurship. It is therefore crucial to assess their entrepreneurial readiness and the internal entrepreneurial environment that may influence their readiness. Descriptive method was used in the study. The participants were tourism and hospitality graduating students chosen using stratified random sampling. Results revealed that majority of the respondents have the intention of starting their own business after graduation because they want to attain financial success, while lack of capital hinders entrepreneurial intention. Furthermore, the respondents have generally high level of readiness in terms of skills in the area of personal maturity and portray a need for achievement and success. The strength of the internal entrepreneurial environment lies on the university's lecturers and curriculum, while its weakness lies on the supporting resources provided for the students. Internal entrepreneurial environment has a high impact on the readiness of the students both in terms of their skills and personal characteristics. The entrepreneurial readiness of the respondents remains the same regardless of their entrepreneurial intention. A program for entrepreneurship development was proposed based on the results of the study.

Keywords: entrepreneurship; hospitality and tourism; curriculum; business; readiness 


\section{Hospitality and tourism students: Are they ready for entrepreneurship?}

\section{Introduction}

The Fast food Industry has been an aggressive sector that had opened its doors for women workers in the past decades. Women employees have progressively partaken special role in the provision of pleasing and hospitable service to the guests. However, studies show that married women who have kids are having a more difficult time in maintaining the both their personal lives and their work without compromising one for the other (Kapoor, \& Khare, 2019). Even if they are happy that they can support their family financially, they need organizations that understand and are considerable enough to assist them in this particular struggle.

Women in the hospitality industry face unique challenges in their career which broadly spans into various areas including family concerns, child care needs, long and irregular working hours, and issues with injustice on pay and promotion. Among the recommended women friendly practices include flexible time of duty, options for part-time work, counselling cell for women, provision of mentors, transportation service, and creche facility in the workplace (Peshave, \& Gupta, 2017).

Haddaji (2017) emphasized the need for family support and application of feminine approach to management in order to facilitate success of women in the restaurant industry. Though there were no highly accentuated gender barriers, it was seen that special approach is needed for women employees for this type of industry. Moreover, this part of the hospitality industry, has a special working environment that contributes to the absence of work-life balance for employees. Demand for hospitality services is unstable and unpredictable. There is also a lack of proper employee training and qualification program. Not to mention the high fluctuation rate in this type of industry (Kupke, 2012). All these factors rose to the growing interest in studying this area of the status of their work and personal life, particularly for the female population.

There are many elements that can influence work life balance. For the purpose of this research, work life balance (WLB) among women employees, their work life satisfaction and work life expectation will be given emphasis. Work Life Balance, as studied by Swarnalatha (2015), may be influenced by the personal environment and the work environment. Personal environment includes the support they are receiving from their family members, availability of support with regards to childcare/dependent care, and their self-management. Work environment covers WLB policies, workplace support, workload and financial assistance. These environmental factors affecting WLB of women employees will be examined further in the present research. Furthermore, assessing the employees' WLB expectation and satisfaction is also crucial in identifying the gap that can be mitigated to protect the welfare of the women employees.

The result of this research would be beneficial mainly to the fast food industry as they reconsider the emerging elements that may affect their work life balance and design strategies to support them. In effect, this may also gain higher consideration for women employees, resulting to higher satisfaction rate leading to better performance that would be appreciated more by the customers. The result of this research would also contribute to the pool of knowledge concerning the gender sensitivity in this specific industry. Lastly, future researchers may gain insights on the factors affecting work life balance, which they can apply to industries other than food and beverage.

This study endeavored to assess the work-life balance on women employees, particularly in the fast food industry. Specifically, it: assessed the work-life balance in the personal environment in terms of: support from family, childcare/dependent care and self-management; assessed the work-life balance in the work environment in terms of: WLB Policies, workplace support, workload, and financial assistance; tested the significant relationship between the personal environment and the work environment; assessed the personal satisfaction of women employees; assessed the work expectation of women employees; tested if there is a link between

74 Consortia Academia Publishing (A partner of Network of Professional Researchers and Educators) 
personal satisfaction and work expectation of women employees, and proposed a plan of action according to the results of the study.

\section{Methodology}

Descriptive-Survey method was used to assess work life balance of the identified respondents. This method is used since the researcher aims to portray distinct phenomena as it happens in the environment. The present research also used triangulation method in the conduct of the research and in acquiring supplementary information from the respondents. In the case of the present study, interview and focal group discussions with the women employees were conducted to further enrich the information gathered. The participants of the study included 175 women employees of fast food establishments in Batangas Province. Using stratified random sampling, they are selected from the eight (8) main fast food restaurant in Batangas Province. The women employees were the main subject for interview and were asked to answer the questionnaire.

An adapted questionnaire from Swarnalatha (2015) which comprised of four parts was used in the conduct of this research. The first part assessed the WLB in the personal environment in terms of support from family, childcare/dependent care, and self-management. The second part assessed the work-life balance in the work environment in terms of WLB policies, workplace support, workload and financial assistance. The third part measured how satisfied are the women employees with regards to their WLB. The fourth part measured the level of expectation of women employees in their WLB.

Through extensive review of literature, the researcher adapted existing questionnaire that would fit the objectives of the study. The survey questions were administered to women employees of fast food establishments in Batangas Province. The participation in the research survey was in a voluntary basis and the respondents were given full freedom in answering the questions. Participants were given time to respond and then the researcher collected the survey questionnaires the following day.

The researcher also conducted follow up interview with respondents in order to validate the results of the study and get supplementary information to support the data that were gathered. The data were then tallied and respective statistical tools were used to process the data. To perform data analysis, the following statistical tools that were used. Weighted mean and ranking were used to assess the work life balance, work environment, life expectation and life satisfaction. In order to assess the relationship between the personal environment and work environment, Pearson-Product Moment Correlation (Pearson- $r$ ) was the statistical tool used.

During the duration of this research, essential ethical behavior was observed. Inform consent was administered prior to distribution of the survey questionnaire to ensure that participants are informed on the benefit of the study, duration of the survey, and that they are not forced, but the participation in the research survey was in a voluntary basis and the respondents were given full freedom in answering the questions. Justice was exercised through fair selection of the respondents. The researcher was also transparent with regards to the information that may have bearing on the decision of the participant to give or withhold their inform consent. No information about the respondents was given outside the educational purpose of this study.

\section{Results and discussion}

\section{Table 1}

Summary table on the work-life balance in the personal environment

\begin{tabular}{lccc}
\hline \multicolumn{1}{c}{ Indicators } & Weighted Mean & Holistic Interpretation & Rank \\
\hline Support from family & 2.99 & High & 1 \\
Childcare/dependent care & 2.78 & High & 2 \\
Self-management & 2.56 & High & 3 \\
Composite Mean & 2.78 & High & \\
\hline
\end{tabular}


Table 1 shows that women employees of fast food restaurants find most of the support from their respective families among all their personal environment. This is attributed to the strong family ties among Filipinos. Members of the family join hand in hand in addressing their daily needs. Such teamwork among families somehow maintains the work-life balance among the employees because it makes their life less stressful and easier to manage. The role of family, friends and the overall social support for married working women was found out to be very important in their marital adjustment. Further, it also provides psychological benefits to the women employee, particularly in elevating their self-confidence, possessing a sense of empowerment and assurance of a better quality of life. Simply the assurance of their support reduces the pressure that the women employees are experiencing due to the bulk of varying roles they play, not just as wife and mother, but also as a striving employee in the organization (Ahmad, \& Khan, 2018).

Furthermore, the item that ranked highest in terms of support from family pertains to the support of family members in paying utility bills. It can then be assumed that majority of them are in situations wherein other members of the family are also receiving monthly income in their respective work. This is common in Filipino family set-up because majority of the families nowadays have both of the parents working in order to finance the needs of the family. It can be then conferred that the spouses of the women employees are assisting them in the family's financial concerns.

The support of the spouse in, both emotionally and practically, contributes in reducing the turnover intention of the women employees and increases their job satisfaction. The team work that is happening between spouses in providing for the needs of the family was found to be supportive for the women employees and is positively influencing them to do better in their work. It can then be concluded that family support system is significant in maintaining satisfaction and balance for the women employees (Huffman, Casper, \& Payne, 2014).

On the other hand, the area of personal environment among women employees of fast food restaurants that needs improvement is the area of self-management. Women, especially mothers, have the tendency to give their all and do anything it takes just to give a good life for their family and children. Sometimes, it comes to a point where they could no longer take care of themselves. Selfless as it may seem, this is not healthy for them in the long run. It may result to being burnt out, inefficiency at work, or even health concerns. It is crucial that the management is also concern about the well-being of the employees and make sure that they are taking care of themselves so that they would be more productive at work.

Chhabra (2017) emphasized the struggle for working women in balancing their work productivity and their role as skilled homemakers. With the current situation among families, it is indeed helpful when women of the family are contributing to the economic needs of the whole family, however, the consequence of this is the difficulty of the women to balance their role as mother and wife, and their role in the company at the same time. This brings about stress among those career-oriented women workers, which is not helpful for the operation as a whole.

Table 2

Summary table on the work-life balance in the work environment

\begin{tabular}{lccc}
\hline \multicolumn{1}{c}{ Indicators } & Weighted Mean & Holistic Interpretation & Rank \\
\hline Work life Balance Policies & 2.18 & Low & 4 \\
Workplace Support & 2.76 & High & 1 \\
Workload & 2.61 & High & 2 \\
Financial Assistance & 2.21 & Low & 3 \\
Composite Mean & 2.44 & Low & \\
\hline
\end{tabular}

Table 2 manifests that workplace support is the area of strength for work-life balance concerning work environment. This is attributed to the systematic lines of communication and clear lines of authority in most of the fast food chains. Women employees are given the support they needed through their supervisors, peers and subordinates. This makes their work more manageable and reduces stress caused by ambiguity of work.

76 Consortia Academia Publishing (A partner of Network of Professional Researchers and Educators) 
Workplace support was found to enhance the positive energy among employee by means of work-life balance and psychological availability (Russo, Shteigman, \& Carmeli, 2014). When women employees are provided with both work and non-work support, it balances their spheres of work and life which then enables them to be more energetic and focused in the tasks at hand. On the contrary, failure to provide these can deplete their energy and be negatively affected psychologically leading to impaired judgment and errors. It is therefore crucial to provide women employees with necessary support in the form of policies and strategies in the workplace to maintain this balance.

The least two item were financial assistance (2.21), followed by WLB policies (2.18), both verbally interpreted as disagree. It is evident that the fast food industry has yet to fully inculcate WLB in their policies and procedures. There is no clear implementation of programs that would aid the work-life balance of the employees. The nature of the service industry also limits the programs that the human resource department can implement for their employees. Aside from employability and individual responsibility, work life balance contributes in maintaining sustainability of the workplace in the tourism and hospitality industry. Considering the complexities of the tourism and hospitality industry, instruments, methods, processes and structures must be formulated and put in place in order to make sure that the workforce of this unique industry is sustained (Baum et al., 2016).

Table 3

Relationship between work life balance in work and physical environment in terms of support from family

\begin{tabular}{lccc}
\hline \multicolumn{1}{c}{ Indicators } & $r$-value & $p$-value & Interpretation \\
\hline Work life Balance Policies & .821 & .000 & Highly significant \\
Workplace Support & .576 & .000 & Highly significant \\
Workload & .757 & .000 & Highly significant \\
Financial Assistance & .763 & .000 & Highly significant \\
\hline
\end{tabular}

The findings shown in table 3 emphasized the significant role that works environment play in the employee's relationship with their respective families. When they receive support from their company, they are also able to have a harmonious relationship with their family. Similarly, when the women employees positive support from their family members, they are able to perform better in their workplace. Both the enrichment from family to work and vice versa are crucial in ensuring that women employees are effective not just in their workplace, but also in their role in the family.

A study inferred that the support to work and family significantly predicts the enrichment of family to work and vice versa, signaling the importance of providing supportive organizational environment and soliciting supportive family arrangements so as to improve the family and work enrichment of the women employees (Jain \& Nair, 2017). Although majority of the literature mainly focus on the support needed from the organization, it is also crucial to look into the support emerging from the family front. These two areas are found to be significantly related in ensuring that the women employees are able to perform the expected roles and responsibilities, both in the workplace and the family. There should also be a consideration on the participation of the family members in ensuring the smooth flow of work and personal life among the women employees in the fast food industry.

\section{Table 4}

Relationship between work life balance in work and physical environment in terms of childcare

\begin{tabular}{lccc}
\hline \multicolumn{1}{c}{ Indicators } & $r$-value & $p$-value & Interpretation \\
\hline Work life Balance Policies & .751 & .000 & Highly significant \\
Workplace Support & .820 & .000 & Highly significant \\
Workload & .949 & .000 & Highly significant \\
Financial Assistance & .858 & .000 & Highly significant \\
\hline
\end{tabular}

Results in table 4 revealed the strong link between the two variables involved. When employees are given leeway in terms of schedule, access to resources and moderate workload, they are more available to take care of 
their elders or children at home. Lack of these supports would result to sacrificing time with the children, which may lead to the employees leaving the company.

One study proved that one of the main factors for women in management pertains to arrangements for work leave and direct provision of services, and this includes childcare or eldercare (Kalysh, Kulik, \& Perera, 2016). Women in the workplace are significantly affected by the provision or lack of consideration when it comes to their care for their dependents, both the children and the elderly. Among the work life practices, those in association with childcare substantiate greatly in their perception of their workplace and the support that it gives them. For most of the women managers, they may consider looking for a company that can provide them with these kinds of arrangements.

\section{Table 5}

Relationship between work life balance in work and physical environment in terms of self-management

\begin{tabular}{lccc}
\hline \multicolumn{1}{c}{ Indicators } & $r$-value & $p$-value & Interpretation \\
\hline Work life Balance Policies & .850 & .000 & Highly significant \\
Workplace Support & .838 & .000 & Highly significant \\
Workload & .975 & .000 & Highly significant \\
Financial Assistance & .920 & .000 & Highly significant \\
\hline
\end{tabular}

Findings in table 5 mean that when women employees are supported at work in terms of their WLB, they are able to take care of themselves more. When employees are bombarded with tasks at work, toxic schedule, and insufficiency of resources, they are compelled to sacrifice their own well-being in the areas of health, spiritual, and relaxation. Generally, women have the tendency for self-sacrifice especially when the welfare of their children is being compromised. They would rather forego of personal leisure just to provide the needs of the family. When put in the situation where they have to choose between personal well-being and that of their children, they would definitely prioritize their children's needs above their own needs. This, however, may be found disadvantageous to the women in the long run, considering the importance of self-management to sustainable productivity.

Instrumental family support given by the organization play a vital role in reducing the experience of employees being burnt out (Wang, Wagner, Boyar, Corman, \& McKinley, 2016). When organization offers support to women employees in order to assist them in alleviating the concerns in their family and personal life, they are less likely to suffer from stress and burn out. It may be in the form of programs and policies especially created for married women that aims to increase their productivity by aiding them with necessary arrangements wherein they can still fulfill their responsibilities in the family. Consequently, it can enable the women employees to focus on their personal well-being, which would then result to a better work performance.

\section{Table 6}

Relationship between personal satisfaction and work expectations

\begin{tabular}{lccc}
\hline & $r$-value & $p$-value & Interpretation \\
\hline Personal Satisfaction vs. Work Expectations & .042 & .578 & Not Significant \\
\hline
\end{tabular}

Result shown in table 6 insinuates that the personal satisfaction of the women employees may be affected by factors other than work expectations. There is a broad scope when it comes to the factors that may affect the employees' personal satisfaction. This may not even be based on the work itself but on the inner well-being of the employee. It may also vary from person to person depending on their experiences and present state of mind. Indeed, there are numerous possibilities for the influencers of the personal satisfaction of the employees; however, the present study reveals that work expectation is not one of them.

A study confirmed that the factor that affects life satisfaction of the employees is task significance (Zhao, Ghiselli, Law, \& Ma, 2016). This infers that the satisfaction of the employees is not based on their work expectation, but on their perceived value of the work that they are doing and its impact to their lives and the 
people they are serving. They may not have focused on their own agenda, but more on the significance of the work that they are doing. On the other hand, lack of task significance may also significantly affect them and their personal satisfaction in a way that negatively impacts them.

Table 7

Proposed plan of action

\begin{tabular}{|c|c|c|}
\hline Key result area/ Objectives & Strategies & Expected outcome \\
\hline $\begin{array}{l}\text { Personal Environment in terms of } \\
\text { Self - Management - providing } \\
\text { sufficient time to relax }\end{array}$ & $\begin{array}{l}\text { - Use it or lose it" vacation policy- } \\
\text { employee's allotted time for vacation } \\
\text { leaves expires at yearend when unused }\end{array}$ & $\begin{array}{l}\text { - Women employees can be } \\
\text { compelled to take necessary } \\
\text { relaxation time }\end{array}$ \\
\hline $\begin{array}{l}\text { Work Environment in terms of } \\
\text { WLB Policies - consider the } \\
\text { possibility for flexible working hours }\end{array}$ & $\begin{array}{l}\text { Flextime - allow the employees to } \\
\text { plot their preferred schedule in advance } \\
\text { before the manager finalize the } \\
\text { schedule for the whole team }\end{array}$ & $\begin{array}{l}\text { - Women employees can have access } \\
\text { to flexible working hours } \\
\text { considering their personal schedules }\end{array}$ \\
\hline $\begin{array}{l}\text { Work Environment in terms of } \\
\text { Workplace Support - allow } \\
\text { employees to give attention for } \\
\text { urgent family or personal issues } \\
\text { immediately }\end{array}$ & $\begin{array}{l}\text { Buddy System - when someone has an } \\
\text { emergency to attend to, her buddy } \\
\text { could handle the task being left behind }\end{array}$ & $\begin{array}{l}\text { - Women employees can be able to } \\
\text { address immediate personal } \\
\text { concerns }\end{array}$ \\
\hline $\begin{array}{l}\text { Work Environment in terms of } \\
\text { Workload - prepare employees to } \\
\text { take bulk of tasks in one whole shift }\end{array}$ & $\begin{array}{l}\text { - Break time - provide a "quiet room" } \\
\text { where they can recharge and relax }\end{array}$ & $\begin{array}{l}\text { - Women employees can be } \\
\text { recharged to take tasks at a full } \\
\text { stretch }\end{array}$ \\
\hline $\begin{array}{l}\text { Work Environment in terms of } \\
\text { Financial Assistance - enable } \\
\text { employees to assist their family to } \\
\text { buy fixed assets }\end{array}$ & $\begin{array}{l}\text { Cooperatives - allow employees to be } \\
\text { part of cooperative where they can } \\
\text { invest and take loans when needed }\end{array}$ & $\begin{array}{l}\text { - Women employees can have access } \\
\text { to possible source of fund for fixed } \\
\text { assets }\end{array}$ \\
\hline $\begin{array}{l}\text { Personal Satisfaction - provide } \\
\text { employees with time on weekend for } \\
\text { shopping and outing with family }\end{array}$ & $\begin{array}{l}\text { Rotational vacation - set schedule in a } \\
\text { way that, one at a time, each employee } \\
\text { can take their day off on weekends }\end{array}$ & $\begin{array}{l}\text { - Women employees can schedule } \\
\text { family time on weekends }\end{array}$ \\
\hline $\begin{array}{l}\text { Work Expectation - prepare } \\
\text { employees to take more challenging } \\
\text { opportunities at work }\end{array}$ & $\begin{array}{l}\text { - Training on time management - train } \\
\text { employees on methods to manage their } \\
\text { time, both personal and at work, to } \\
\text { improve productivity }\end{array}$ & $\begin{array}{l}\text { - Women employees can take on } \\
\text { more challenging opportunities at } \\
\text { work due to a more managed time }\end{array}$ \\
\hline
\end{tabular}

Table 7 presents the proposed action plan based on the result of the study. This may be presented to the human resource department of the participating fast food establishments for further improvement of their work-life balance policies particularly for their women employees.

\section{Conclusion}

Women employees generated support from family but needs to improve their self-management. They felt that they are being supported in their workplace, but would appreciate a more detailed and implemented work-life balance policy. A strong link was identified between work and personal environment. Women employees were able to get sufficient sleep, but cannot spend the weekend with their families. There was a high expectation on the management to consider the WLB of women employees to promote their positive health conditions but they have low personal satisfaction. No correlation was found between personal satisfaction and work expectation. Action plan was proposed for the improvement of WLB with regards to women employees working in fast food establishments.

\subsection{Recommendation}

The human resource department of the fast food restaurants may implement a detailed work-life balance policy that may benefit their women employees. Women employees may express to their superiors the necessary support they need to improve their work-life balance. Restaurant owners can adapt an employee-focused mindset, considering that happy employees will result to happy customers. The academe may train hospitality students to practice work-life balance as early as during their learning years in order to prepare them with habits that they can carry on when they are already working. Future researchers can conduct similar study relevant to gender and 
Pulhin, J. C.

development using qualitative approach to extract specific work-life balance practices needed by the women employees.

\section{References}

Ahmad, M., \& Khan, A. (2018). Social support and marital adjustment in married working women. Education, Sustainability and Society, 1(2), 5-7. https://doi.org/10.26480/ess.02.2018.05.07

Baum, T., Cheung, C., Kong, H., Kralj, A., Mooney, S., Thanh, H., Ramachandran, S., Ruzic, M., \& Siow, M. (2016). Sustainability and the tourism and hospitality workforce: A thematic analysis. Sustainability, 8(8), 809. https://doi.org/10.3390/su8080809

Chhabra, S. (2017). Stress among working women: Maintaining balance as housewives or productive employees. International Journal in Applied Studies and Production Management, 3(3), 78-83.

Haddaji, M. (2017). Women chefs' access barriers to Michelin stars: A case-study based approach. Journal of Culinary Science and Technology, 15(4), 320-338. https://doi.org/10.1080/15428052.2017.1289133

Huffman, A., Casper, W., \& Payne, S. (2014). How does spouse career support relate to employee turnover? Work interfering with family and job satisfaction and mediators. Journal of Organizational Behavior, 35(2), 194-212. https://doi.org/10.1002/job.1862

Jain, S., \& Nair, S. (2017). Work support and family support as predictors of work-to-family enrichment and family-to-work enrichment. Global Business Review, 18(5), 1307-1324. https://doi.org/10.1177/0972150917710332

Kalysh, K., Kulik, C., \& Perera, S. (2016). Help or hindrance? Work-life practices and women in management. The Leadership Quarterly, 27(3), 504-518. https://doi.org/10.1016/j.leaqua.2015.12.009

Kapoor, A., \& Khare, A. (2019). A study on work life balance among women labor in garment units of NCR, India. International Journal of Management, 10(1), 19-25. https://doi.org/10.34218/IJM.10.1.2019/004

Kupke, D. (2012). Work-life balance: Challenges and opportunities for the hospitality industry. Munich: Grin Verlag.

Peshave, J., \& Gupta, K. (2017). Challenges in the career progression of women in hospitality industry: A review of literature. International Journal of Commerce and Management Research, 3(2), 158-165. https://doi.org/10.21863/ATITHYA/2016.2.1.022

Russo, M., Shteigman, A., \& Carmeli, A. (2014). Workplace and family support and work-life balance: Implications for individual psychological availability and energy at work. The Journal of Positive Psychology, 11(2), 173-188. https://doi.org/10.1080/17439760.2015.1025424

Swarnalatha, T. (2015). An empirical analysis of work life balance on women employees: A study with reference to banking sector at Chennai [Doctoral dissertation]. Manonmaniam Sundaranar University, India.

Wang, P., Wagner, T., Boyar, S., Corman, S., \& McKinley, R. (2016). The relationship between organizational family support and burnout among women in the healthcare industry: Core self-evaluation as moderator. In M. Connerley \& J. Wu (Eds.), Handbook on well-being of working women (pp. 283-296). Dordrecht: Springer. https://doi.org/10.1007/978-94-017-9897-6_17

Withiam, G. (2013). Work-family imbalance leads some employees to leave. Hotel Management, 228(7), 17.

Zhao, X., Ghiselli, R., Law, R., \& Ma, J. (2016). Motivating frontline employees: Role of job characteristics in work and life satisfaction. Journal of Hospitality and Tourism Management, 27, 27-38. https://doi.org/10.1016/j.jhtm.2016.01.010 